\title{
Istanbul 2003
}

\author{
By Gönül Dönmez-Colin
}

Fall 2003 Issue of KINEMA

\section{ISTANBUL INTERNATIONAL FILM FESTIVAL 2003}

(April 12-27, 2003) celebrated its $22^{\text {nd }}$ birthday this spring with almost 200 films from around the world. What began as Cinema Days in the eighties in this cosmopolitan city of film-lovers has now become a prestigious event that connects different cultures just as the city of over fifteen million inhabitants itself, which unites the continents of Europe and Asia with its spectacular Bosporus. The festival venue in the Beyoglu district, the ancient Pera, which has become the Soho of Istanbul, adds to this atmosphere with its numerous book and CD/DVD shops and bohemian cafes that stay open past midnight.

Since the closure of the cinematheque in the eighties by the military regime of the period, the festival has shouldered the dual role of preserving the film culture while presenting the best crop of the year, which means that the main programs, the National and International Competition, Young Stars of the World Cinema, Cinema: the Mirror of Our Times and From the World Festivals are supplemented with various homages and tributes, the bulk of which is shown in the first half of the two-week-long festival. Foreign guests are invited during the second week when the most recent Turkish films are showcased.

The films that compete for the coveted Golden Tulip award are expected to have some relation to art and the artist or to be adaptations from literary works. The fact that Istanbul takes place only a few days before Cannes makes it rather difficult to find quality films for the International Competition, which had not been previously screened elsewhere. This was perhaps one of the reasons for the rather average quality of the thirteen competing films in general this year. Nevertheless, a handful of outstanding works made the visit a worthwhile experience.

Personal Velocity by Rebecca Miller (who happens to be Arthur Miller's daughter) based on her collection of stories focused on three women somewhat scarred by their past and their relationship with their father. The time span covered in the three episodes of the film is the period when they decide to take destiny in their own hands. Miller tries to connect these stories through a chance event that each protagonist encounters or experiences and this is the weak point of the film as the way she goes around the task is somewhat artificial. The film was shot in digital, which gives a feeling of intimacy that all players convey with a natural style.

Tan De Repente (Suddenly) by Diego Lerman from Argentina is a film about relationships in a constantly changing world. The restless wondering of the young souls is very much a la early Wenders or Jarmusch, but some elements of the narration are definitely Latin American, particularly the humour, which has universal appeal as well.

French filmmaker Jean-Pierre Sinapi, who has won several awards with his first feature, Nationale 7 (Uneasy Riders), continues the socially engaged approach of his earlier film with Vivre me tue (Life Kills Me), the story of two brothers in opposite extremes, who are both unemployed. Coming from an Arab immigrant family, albeit a model one - the grandfather was killed serving the French army and the father retired after working for the railways all his life to give his sons a good education - does not help matters either. Paul, the elder with a Master's degree in Literature represents the 'soul', whereas Daniel, the younger one, who has preserved the innocence of childhood despite realities of life, is focused on his body, but both are in search of a firm identity and a better self-image. (Well-meant, but a bit too schematic!) Thrown in is romance for Paul with a kindred soul, an unattractive but intellectual literature freak also with a rather shaky self-esteem. But the film is much more than a love story, although love is one of the central themes - parental love, brotherly love, love for the adopted country, love for one's own body or soul pitted against forces that betray and destroy beautiful human qualities such as love. Remarkable performances from Sami Bouajila and Jalil Lespert enforce the sound dramatic structure to create an unpretentious film that stays with the audience longer than big budget, fast moving, fast-talking technical acrobatics that are the usual fare at the moment. 
Hafid (The Sea), an Iceland-France-Norway co-production by Baltasar Kormakur, who made his debut with 101 Reykjavik (2000) and has acted in the films of Fridrik Thor Fridriksson as well as working as a theatre director, is constructed in the tradition of Scandinavian dramaturgy going back to Ibsen. The narrative progresses at two parallel levels: mundane problems of a disfunctioning family - sex, adultery, betrayal, incest, et al- and the socio-economic advancements that inadvertently change an isolated fishing community (an island onto itself), threatening to swallow up its customs and traditions for the sake of globalisation. In that sense, it is significant that, the pregnant fiancée, the gentle and soft-spoken intruder comes from mainland Europe, France. Her relationship with the father of the unborn child, however, is somehow ambivalent, as he seems to favour incestuous liaisons despite the fact that his foot is firmly set on her country.

The script, the photography and the performances are beyond reproach in this film, which somehow does not work when all is put together, except for true lovers of intense Scandinavian family dramas that deliver through violent emotional explosions.

From Mexico, Carlos Carrera's El Crimen del Padre Amaro (The Crime of Father Amaro), was boycotted by the Catholic church but chosen as one of the five films to compete for the Academy Award in the foreign language category. The film exposes the hypocrisy of the men of the frock whose basic interest seems to be their own. The style chosen to deliver this message, however, is more suitable to television than the wide screen.

Madame Sata by Karim Ainouz, a co-production between Brazil and France is a highly entertaining film, particularly thanks to the acting of Emiliano Queiriz, the cinematography of Walter Carvalho and the powerful music that evokes the seedy, sinful and seductive Lapa district of nineteen-thirties Rio, where many Blacks and marginals gathered and where people took liberties. Joao Francisco dos Santos, an illiterate black man, a notorious street-fighter, convict, transvestite, cross-gender dresser and father of seven adopted children lived in that milieu never letting himself once be victimised. Exchanged for a mule by his slave mother at a very early age, dos Santos sought means of transforming the rage inside him, mainly because he loved life and never lost hope. The film presents him as part of a very unconventional family that includes Laurita, a marginal performer, her daughter and their maid, an ascorbic antidote to the ideal bourgeois family of the period. Transformed into Madame Sato, the inspiration of dos Santos is Hollywood but also Josephine Baker, not to mention the war god, Ogun. The carnival scene at the end when emotions reach a crescendo looks very real and it is hard to imagine that it was all staged and shot on Super 8. Then again, it is like the character of Madame Sato, which blurs the boundaries of real and make-believe.

In the National Competition section, choices were eclectic but surprises very few among the eight films presented. Veteran filmmakers Ömer Kavur and Yusuf Kurçenli competed with new comers such as Ümit Cin Güven and with one of the strongest voices of new Turkish cinema, Nuri Bilge Ceylan.

Potentially interesting themes such as street children, child abuse, folklore, tradition, migration and urban and rural dilemmas were explored employing diverse approaches, but surface treatment. Without making apologies for the filmmakers working under dire financial circumstances, one may say that there seemed to be a general lack of creativity and originality in this year's crop, except for some courageous attempts that showed noteworthy results.

Srı Cocukları (Children of Secret) by Aydın Sayman and Ümit Cin Güven focused on a pressing social problem, the street children, but the lives of these youngsters of misfortune appeared completely sanitised and their experiences unbelievably romantic. After spending days sniffing paint solvent in street corners, the little heroes managed to remain pure and clean, not only spiritually but also physically throughout the film. Beautiful shots of picturesque Istanbul were interspersed with or without reason turning the film into a tourism poster. Subplots with little connection to the main plot resulted in a meandering narrative. The film could have benefited more from a thorough study of the subject before venturing to transfer it to screen.

Martılar Açken (When the Seagulls are Hungry) by Bülent Pelit with a background in television would have been more suitable to that medium. Depleted metaphors such as the epileptic hero, the classic themes of prostitute-pimp relations and solidarity among the downtrodden were once again decorated with postcard views of Istanbul bringing nothing new. On the plus side were the convincing performance of Meral Oğuz as the ageing prostitute and the soundtrack of the film, particularly the heart-rending theme song, "Martılar 
Açken".

Gönlümdeki Köşk Olmasa (House of Hearts) by Elisabeth Rygard, a Danish documentarian, was made in Turkey with a Turkish cast. The director's keen interest in the Anatolian folklore and particularly the folk songs and the mystic philosophy was the underlying motivation of this sincere approach to Turkish peasant life and the natural performance of the boy as the leading character was heart rendering. However, the essence was lost somewhere and the issue of the immigrants that the film purported to expose did not materialise.

Veteran Yusuf Kurçenli's first fiction film since 1994, Gönderilmemiş Mektuplar (Unsent Letters), which was rejected by a large number of audience as belonging to a totally different epoch was in some ways an interesting experiment if the director had that in mind. The film narrated an unrequited love in the tradition of Yesilçam (a Turkish Hollywood of sorts without the studios) melodramas of 1960s and 1970s. The fact that the main leads were shared by two important stars of that genre, Türkan Şoray (crowned the sultana of Turkish cinema) and Kadir Inanir added to the atmosphere of nostalgia, but the film had very little to offer to today's audience. A cliché-laden dialogue was laughing matter for the young generation.

Büyük Adam Küçük Aşk (Hejar), which was banned from entering the competition last year, had a chance to compete this year. Handan Ipekci's political drama tries to approach the issue of Turkish and Kurdish relations through an unusual friendship between a retired Kemalist judge and an orphaned Kurdish girl. The episodes dealing with the suppression of a language in a literal and a metaphoric sense, the role of the assimilated Kurdish maid as a mediator between the two opposing forces and the emotional transformation of the strong willed little girl are powerful elements. However, one wonders if scenes such as the one when the old judge takes the girl on a shopping spree were really necessary.

O Simdi Askerde (He's in the Army Now) by Mustafa Altioklar, who has broken box-office records with films such as Istanbul Kanatlarimin Altinda (Istanbul Beneath my Wings) and Ağır Roman (Cholera Street) has succeeded making another commercial winner in tune with his concept of cinema as pure entertainment for the masses. The clever dialogue full of sharp one-liners and the appearances of popular media figures guaranteed a fun evening for the local audience, but the foreign guests found little interest in this remake of remakes on army eccentrics.

Omer Kavur is one of the finest directors of Turkish cinema with such unforgettable works as Anayurt Oteli (Motherland Hotel) and Gizli Yüz (The Secret Face). His latest work, Karsilaşma (Encounter) is a psychological drama about life, love and overlapping destinies. The opening scene in a hospital ward where patients receive chemotherapy is very powerful, particularly for the role it plays in determining the destiny of the main character. The theme of quest that is the overriding metaphor of Kavur's previous films is also evident here. The visuals are used to the best advantage. However, acting is not very convincing and the twists and turns of the plot, not intriguing enough to hold the narrative together.

Last but not the least is the film of Nuri Bilge Ceylan, Uzak (Distant) which was screened before going on to Cannes, where it received the Grand Prix of the jury. Ceylan's film is somewhat of a continuation of his previous films. The rural cousin who was asking the filmmaker to find him a job in the city in Mayıs Sikıntısı (Clouds of May) knocks on the door of the protagonist who is a professional photographer. The smell of his shoes, the aroma of his cheap cigarettes, the commonness of his language, most of all his presence disturb the urbanite loner who is set in his ways, which, incidentally are more like circles. Nothing much happens in the film. The snow changes to slush and one day the urban cousin removes himself from the unfriendly space. Uzak is a quiet, intimate and unpretentious film about ordinary lives; it touches deep emotions subtly and leaves the audience with images to reflect, to turn over and relive after they disappear from the screen.

In other sections of the festival, several galas were held, supported by the main sponsor of the festival, Turkcell. (Operated by the Istanbul Culture and Arts Foundation, the festival does not receive monetary support from the government.) These were in general the most talked about films of the year: Hollywood Ending by Woody Allen, Punch-Drunk Love by Paul Thomas Anderson, The Dancer Upstairs by John Malkovich, et al.

In the In Memoriam section, Yasujiro Ozu and William Wyler were honoured. The latter's films were presented by his daughter Catherine Wyler, who was a member of the international jury. 
The tributes section showed films of Claude Chabrol, Brian De Palma, Edward Yang and Turkish Zeki Okten whose collaboration with Yilmaz Güney resulted in classics such as Suru (The Herd, 1979).

A special guest of the festival, documentarian Estela Bravo drew enthusiastic crowds with her socially engaged films shown in the section, The Witness of her Times: Estela Bravo and Bravo was presented with the Cinema Honour Award.

The festival which rolled up the curtain with Chen Kaige's Han ni zai yiqi (Together), about a precocious thirteen-year-old boy's emotional and intellectual evolution through his music, closed with En la Ciudad sin limites (The City of No Limits, Spain-Argentina) by Antonio Hernandez, an atmospheric drama focusing on the tormented life of a terminally ill men, seen through the eyes of his idealist son.

The jury, presided over by filmmaker Jim Sheridan gave the Golden Tulip to Tan De Repente by Diego Lerman and the Special Jury Prize to Personal Velocity by Rebecca Miller. Hafid by Baltasar Kormakur received the FIPRESCI award in the international competition and Uzak by Nuri Bilge Ceylan in the national competition. Uzak also received the Best Turkish Film of the Year award. Nuri Bilge Ceylan was chosen as the Best Turkish Director of the Year. People's Choice award in the international competition went to Personal Velocity by Rebecca Miller and in the national competition, to Büyük Adam Küçük Aşk by Handan Ipekçi.

\section{Author Information}

Gönül DÖNMEZ-COLIN is an independent researcher and writer whose publications include Women, Islam and Cinema, Cinemas of the Other: A personal Journey with Filmmakers from the Middle East and Central Asia, Cinema of North Africa and the Middle East (ed.); Turkish Cinema: Identity, Distance and Belonging (Reaktion Books), and Routledge Dictionary of Turkish Cinema (2014). 